\title{
Dry Juan de Fuca slab revealed by quantification of water entering Cascadia subduction zone
}

* J.P. Canales ${ }^{1}$, S.M. Carbotte ${ }^{2}$, M.R. Nedimović ${ }^{3}$, H. Carton ${ }^{4,2}$

${ }^{1}$ Department of Geology and Geophysics, Woods Hole Oceanographic Institution, Woods Hole, MA 02540, USA.

${ }^{2}$ Lamont-Doherty Earth Observatory, Columbia University, Palisades, NY 10964, USA.

${ }^{3}$ Department of Earth Sciences, Dalhousie University, Halifax, Nova Scotia B3H4J1, Canada.

${ }^{4}$ Institut de Physique du Globe de Paris, 75252 Paris Cedex 05, France.

*Corresponding Author. E-mail: jpcanales@whoi.edu 


\section{Summary}

Water is carried by subducting slabs as a pore fluid and in structurally bound minerals, yet no comprehensive quantification of water content and how it is stored and distributed at depth within incoming plates exists for any segment of the global subduction system. Here we use seismic data to quantify the amount of pore and structurally bound water in the Juan de Fuca plate entering the Cascadia subduction zone. Specifically, we analyse these water reservoirs in the sediments, crust and lithospheric mantle, and their variations along the central Cascadia margin. We find that the Juan de Fuca lower crust and mantle are drier than at any other subducting plate, with most of the water stored in the sediments and upper crust. Variable but limited bend faulting along the margin limits slab access to water, and a warm thermal structure resulting from a thick sediment cover and young plate age prevents significant serpentinization of the mantle. The dryness of the lower crust and mantle indicates that fluids that facilitate episodic tremor and slip must be sourced from the subducted upper crust, and that decompression rather than hydrous melting must dominate arc magmatism in central Cascadia. Additionally, dry subducted lower crust and mantle can explain the low levels of intermediate-depth seismicity in the Juan de Fuca slab. 
How much and at what depth water is released from subducting slabs ${ }^{1}$ depends on how and where it is stored within the down-going plate ${ }^{2}$. Water is stored both as a fluid in pore spaces $\left(\mathrm{H}_{2} \mathrm{O}^{\text {pore }}\right)$ and structurally bound $\left(\mathrm{H}_{2} \mathrm{O}^{+}\right)$in secondary minerals resulting from hydrothermal alteration ${ }^{3}$, with $\mathrm{H}_{2} \mathrm{O}^{\text {pore }}$ released from the plate at shallower depths in the subduction system ${ }^{2}$. The relative contribution of each storage mode to oceanic plate hydration differs for sediments, upper crust, lower crust and lithospheric mantle due to the differences in composition, porosity, and temperature among these layers. Quantifying the hydration state of all sections of an incoming plate is of fundamental importance for understanding subduction processes such as dynamics of the mantle wedge $^{4}$, generation of arc magmas ${ }^{5}$, and the seismogenic behaviour of the plate interface $^{6}$, as well as for constraining global fluxes of volatiles ${ }^{7}$.

Constraints on sediment and crustal hydration from drilling exist ${ }^{7}$, but their restriction to a few locations limits their broader relevance, as they have to be extrapolated to other settings and crustal ages. Geophysical studies constrain hydration of incoming oceanic mantle at a number of subduction systems, but sediment or crustal water contents are rarely estimated by these studies, and the partition of water into $\mathrm{H}_{2} \mathrm{O}^{\text {pore }}$ and $\mathrm{H}_{2} \mathrm{O}^{+}$as a function of depth has not been fully addressed, resulting in overestimation of incoming mantle hydration $^{8}$ (Supplementary Table S1 and references therein). Thus, there is not a single segment of the global subduction system for which the water content and distribution within the incoming plate has been estimated in a comprehensive manner.

At the Cascadia subduction zone (Fig. 1) the relatively young age (5-9 $\mathrm{Ma}^{[9]}$ ), moderate convergence rate $\left(34.8 \mathrm{~mm} \mathrm{yr}^{-1}\right.$ relative to North America $\left.{ }^{9}\right)$, and thick sediment cover (Fig. 2, Table S1) of the Juan de Fuca (JdF) plate at the onset of subduction all contribute to a warm thermal structure ${ }^{10}$ that is thought to limit the water storage capacity of the plate. This is particularly important for the lithospheric mantle, which represents the largest potential water reservoir for all oceanic plates, where formation of high-water 
content mineralogies such as serpentine is severely reduced at temperatures above $\sim 350$ ${ }^{\circ} \mathrm{C}^{[11]}$. This expected overall limited hydration of the JdF plate at the Cascadia deformation front $(\mathrm{CDF})$ is apparently at odds with the many observations attributed to fluids derived from slab dehydration. These include low seismic velocities in the fore-arc mantle interpreted as a serpentinized region ${ }^{12}$, elevated Poisson's ratio in the subducting crust $^{13}$, episodic non-volcanic tremor and slow slip (ETS) events ${ }^{14}$, intra-slab seismicity thought to result from dehydration embrittlement ${ }^{15}$, low electrical resistivities in the forearc mantle ${ }^{16}$, and geochemical evidence that fluids in southernmost Cascade magmas are sourced from hydrated subducted mantle ${ }^{17}$.

Water is incorporated into the JdF plate as it evolves through different hydrogeological regimes from accretion at the $\mathrm{JdF}$ ridge to subduction at Cascadia ${ }^{18-21}$ (Fig. 1). Ridge segment boundaries propagate along the axis creating pseudofaults that are preserved in the interior of the plate ${ }^{9}$ (Fig. 1). These structural anomalies are characterised by sheared and fractured crust with higher potential for water storage ${ }^{18}$. In the interior of the plate, a complex stress state ${ }^{22,23}$ contributes to increased deformation in the southeastern sector of the plate (as indicated by elevated levels of intra-plate seismicity, Fig. 1) and therefore to its potential for hydration ${ }^{20}$. Near the CDF, seismic reflection images document plate faulting in response to bending stresses, with more pervasive faulting extending through the crust and into the mantle offshore Oregon than offshore Washington $^{24}$. Thus, the hydration potential of the incoming JdF plate is variable along Cascadia due to both structural heterogeneities inherited from accretion at the ridge as well as a variable stress regime in the interior of the plate and along the margin.

To quantify the water content of the JdF plate, we conducted a controlled-source wide-angle seismic and multi-channel seismic reflection survey of the JdF plate. Data were collected along two transects across the full width of the plate and along a profile sub-parallel to the CDF, as well as along three fan profiles (Fig. 1) ${ }^{18,24}$. We use effective 
medium theory ${ }^{25}$ to convert the tomographically determined $P$-wave velocity $(V p)$ along profile L3 (Fig. 2a) to water content estimates for the plate. We determine, for the first time, the relative contributions of $\mathrm{H}_{2} \mathrm{O}^{\text {pore }}$ and $\mathrm{H}_{2} \mathrm{O}^{+}$within the sediments, upper and lower crust, and uppermost mantle reservoirs by assuming that the porosity for each particular layer is filled with a combination of fluid water and hydrated alteration mineralogies (Methods).

\section{Water content of the Juan de Fuca plate}

The proto-décollement within the incoming sediments is located just above the basement offshore Washington at the intersection of profiles L2 and L3 $\left(47^{\circ} 25^{\prime} \text { N, Fig. } 1\right)^{24}, 0.3-1.4$ $\mathrm{km}$ above basement to the south of a buried seamount at $45^{\circ} 25^{\prime} \mathrm{N}^{[24,26]}$, and $<0.6 \mathrm{~km}$ above basement between $45^{\circ} 50^{\prime}-47^{\circ} 15^{\prime} N^{27,28}$ (Fig. 2a). Sediment velocities below the proto-décollement range between 3.0-4.2 $\mathrm{km} \mathrm{s}^{-1}$ (Fig. 2b), from which we estimate an average $\mathrm{H}_{2} \mathrm{O}^{\text {pore }}$ content of $4.1 \pm 1.8 \mathrm{wt} \%$ (Fig. 3a, Table $\mathrm{S} 1$ ). The amount of sedimenthosted water actually subducted will differ slightly from what we estimate along L3 because of changes in the stratigraphic level of the décollement ${ }^{26}$, which are a couple of hundred meters at most ${ }^{27,28}$.

Upper crustal $V p$ values within the extrusive Layer $2 \mathrm{~A}\left(4.1-4.6 \mathrm{~km} \mathrm{~s}^{-1}\right)$ and within the intrusive Layer 2B (5.1-5.8 $\left.\mathrm{km} \mathrm{s}^{-1}\right)$ are below the $V p$ expected for unfractured basalt and diabase at $\sim 200^{\circ} \mathrm{C}$ (Fig. 2b). From the differences in observed and expected velocities we estimate that Layer $2 \mathrm{~A}$ stores on average $3.0 \pm 0.4 \mathrm{wt} \%$ and $1.8 \pm 0.2 \mathrm{wt} \%$ of $\mathrm{H}_{2} \mathrm{O}^{\text {pore }}$ and $\mathrm{H}_{2} \mathrm{O}^{+}$, respectively, and Layer $2 \mathrm{~B}$ stores $2.3 \pm 0.4 \mathrm{wt} \%$ and $0.27 \pm 0.05 \mathrm{wt} \%$ of $\mathrm{H}_{2} \mathrm{O}^{\text {pore }}$ and $\mathrm{H}_{2} \mathrm{O}^{+}$, respectively (Fig. 3a).

At the northern end of the profile, lower crustal $\mathrm{Vp}$ is consistent with our estimate for unaltered, non-porous gabbroic rock at $350^{\circ} \mathrm{C}$ (Fig. 2a, c), indicating a nominally dry, unfractured lower JdF crust approaching the CDF offshore the Olympic Peninsula. 
However, to the south of $47^{\circ} 30^{\prime} \mathrm{N}$ lower crustal velocities are consistently lower than expected. This pattern requires a southward increase in lower crustal $\mathrm{H}_{2} \mathrm{O}^{\text {pore }}$ content (Fig. 3b), with $\mathrm{H}_{2} \mathrm{O}^{+}$content remaining very low $(<0.01 \mathrm{wt} \%$, Fig. 3c, Table $\mathrm{S} 1)$. There are short-wavelength variations with local $V p$ minima correlating with the presence of propagator wakes (Fig. 2c). At these locations we estimate an $\mathrm{H}_{2} \mathrm{O}^{\text {pore }}$ content of $0.11 \pm 0.02 \mathrm{wt} \%$ (Fig. 3b). Aside from these local heterogeneities, $\mathrm{H}_{2} \mathrm{O}^{\text {pore }}$ content between $45^{\circ} 50^{\prime} \mathrm{N}-47^{\circ} \mathrm{N}$ is relatively constant $(0.07 \pm 0.03 \mathrm{wt} \%$, Fig. $3 \mathrm{~b}$, Table $\mathrm{S} 1)$. Our results show that $45^{\circ} 50^{\prime} \mathrm{N}$ represents a significant boundary in the porosity structure and hydrated state of the lower crust entering Cascadia: at $45^{\circ} 50^{\prime} \mathrm{N} \mathrm{H}_{2} \mathrm{O}^{\text {pore }}$ content in the lower crust shows an abrupt increase to a maximum value of $0.15 \pm 0.05 \mathrm{wt} \%$ at $45^{\circ} 30^{\prime} \mathrm{N}$, and remains relatively high south of this latitude $(0.09-0.15 \pm 0.04 \mathrm{wt} \%$, Fig. $3 b)$.

Mantle velocities range between 7.54-8.10 $\pm 0.04 \mathrm{~km} \mathrm{~s}^{-1}$ (Fig. 2d), and in general show a pattern of decreasing values from $47^{\circ} \mathrm{N}$ to $45^{\circ} 10^{\prime} \mathrm{N}$ similar to those found in the lower crust. This pattern is disrupted by the presence of the $45^{\circ} 05^{\prime} \mathrm{N}$ propagator wake, within which we find the highest mantle velocity in our model. Taking into account azimuthal mantle anisotropy in our measurements (Methods), we calculate $V p$ for a dry mantle at a temperature of $500{ }^{\circ} \mathrm{C}$ to be $\sim 7.88 \mathrm{~km} \mathrm{~s}^{-1}$ along the profile (Fig. 2c). Our tomography model is consistent with this value north of the $46^{\circ} 50^{\prime} \mathrm{N}$ propagator wake (within the estimated uncertainty bounds), which indicates a nominally dry mantle along this part of the profile, with both $\mathrm{H}_{2} \mathrm{O}^{\text {pore }}$ and $\mathrm{H}_{2} \mathrm{O}^{+}$values $\leq 0.04 \mathrm{wt} \%$ (Fig. 3b-d). Along the paleo segment bounded by the two propagators, tomography-derived mantle velocities are, however, lower than expected for unaltered mantle, indicating pore water contents of up to $0.11 \pm 0.03 \mathrm{wt} \%$ (Fig. $3 \mathrm{~b}$ ) and very low $\mathrm{H}_{2} \mathrm{O}^{+}$values (up to $0.024 \pm 0.007 \mathrm{wt} \%$ for an alteration mineral assemblage consisting of talc, chlorite, and amphibole, Fig. 3c, or $0.04 \pm 0.01 \mathrm{wt} \%$ for an alteration mineral assemblage consisting of serpentine, chlorite, and amphibole, Fig. 3d). 
At, and to the south of the $45^{\circ} 05^{\prime} \mathrm{N}$ propagator wake, the assumption of $6 \%$ mantle anisotropy along the spreading direction is clearly not valid because it predicts $V p$ significantly lower than what we measured (Fig. 2c). In fact, the highest measured $V p$ is close to what we would expect for a dry mantle in the absence of mantle anisotropy. This indicates that the $45^{\circ} 05^{\prime} \mathrm{N}$ propagator wake marks a disruption in the shallow mantle anisotropic fabric, as indicated by the more complex dependence of $P n$ traveltime with azimuth in Fan 3 data compared with data from Fans 1 and 2 (Figs. S4, S5, S6). Therefore, the uncertainty in mantle anisotropic structure at and to the south of the $45^{\circ} 05^{\prime} \mathrm{N}$ propagator wake makes mantle water content estimates at this location less well constrained, although they range from nominally dry mantle up to values similar to those north of the propagator (Fig, 3b-d).

We estimate that the upper crust contributes between 5,200 and 7,400 $\mathrm{Tg} \mathrm{Myr}^{-1} \mathrm{~km}^{-1}$ to the subduction flux of water at Cascadia (Fig. 1, Methods). In contrast, the combined lower crust and upper mantle subduction flux is an order of magnitude lower than that contributed by the upper crustal reservoir (Fig. 1).

\section{Controls on Juan de Fuca plate hydration}

The upper crustal water content at Cascadia and its contribution to subduction flux of water generally decreases southwards, but it is dominated by fluctuations along the margin at wavelengths of a few tens of km (Fig. 1, 3a). In contrast, lower crustal/upper mantle water content shows a marked change at $45^{\circ} 50^{\prime} \mathrm{N}$, where subduction flux of water approximately doubles from an average of $460 \mathrm{Tg} \mathrm{Myr}^{-1} \mathrm{~km}^{-1}$ north of this latitude to an average of $920 \mathrm{Tg} \mathrm{Myr}^{-1} \mathrm{~km}^{-1}$ to the south (Fig. 1). Although the total amount of lower crustal/upper mantle water is small, the relative change in water content at $45^{\circ} 50^{\prime} \mathrm{N}$ is significant and we interpret it as resulting from an increase in plate-bending faulting south of this latitude that enhances water penetration to lower crustal and upper mantle 
levels. This interpretation is based on the contrasting characteristics of bending faults along profiles L1 and L2 (Fig. 1) ${ }^{24}$. The origin of this along-margin variation in the extent of bending faulting and associated plate hydration has been attributed to variations in the curvature of the slab ${ }^{24}$ and in the orientation of the pre-existing oceanic fabric ${ }^{20,24}$ (Table S1). The elevated levels of seismicity in the southeastern sector of the JdF plate (Fig. 1) indicate that this region is deforming more extensively than the rest of the plate interior. Spatially variable intra-plate deformation, which has been attributed to JdF ridge and Blanco TF push ${ }^{22}$ and/or increase in strain rate along the $\mathrm{CDF}^{23}$, is thus likely an additional factor contributing to along-margin variations in the extent of bending faulting.

JdF plate upper crustal water contents are similar to those inferred from seismic observations at other subduction zones or measured in drilled samples, but lower crustal and mantle water contents are significantly lower than inferred for any other subduction zone (with the possible exception of western Nankai Trough, Table S1). Seaward from the CDF off Oregon, bending faults extend into the mantle ${ }^{24}$ as in a number of other subduction zones ${ }^{29,30}$. However, the along-strike variability in bend faulting at the JdF plate, along with the overall lower magnitude of bend faulting and lower fault density compared to other incoming plates limits water penetration into the lower crust/upper mantle $\mathrm{e}^{20,24,30}$. This, together with a warm thermal structure that prevents significant formation of hydrated minerals, explains the dryness of the lower crust/upper mantle in this region.

\section{Incoming plate structure and fore-arc processes}

The propagator wakes at $45^{\circ} 05^{\prime} \mathrm{N}$ and $46^{\circ} 10^{\prime} \mathrm{N}$ and buried seamount at $45^{\circ} 25^{\prime} \mathrm{N}$ contribute significantly to $\mathrm{H}_{2} \mathrm{O}^{\text {pore }}$ content, particularly at upper crustal levels (Figs. 1, 3a, b), indicating that volcanic and tectonic features inherited from accretion at the ridge axis are local hydration anomalies entering the subduction zone. The location of these features 
landward from the CDF coincide with the segmentation in the extent of paleo megathrust ruptures inferred from turbidite records ${ }^{31}$ (Fig. 1). Increased fluid released from the subducted hydrated pseudofaults may thus contribute to small-scale plate interface heterogeneities that act as rupture barriers, as also inferred for the Illapel (Chile) earthquake region ${ }^{32}$. However, because of the obliquity of these features relative to the convergence direction and the strike of the CDF (Fig. 1), and the uncertainty in the downdip width of the seismogenic zone $e^{33}$, the precise latitudes at which subducted propagators may influence megathrust properties are unconstrained.

Previous studies resolve a $3 \pm 1-\mathrm{km}$-thick low velocity zone down to depths of at least $45 \mathrm{~km}$ beneath North America, interpreted as hydrated oceanic upper crust over a lowporosity lower crustal layer ${ }^{34,35}$, similar to the hydration distribution we determine for the JdF plate at the CDF. This indicates that the general hydration structure of the shallow portion of the slab is inherited from the structure of the plate at the onset of subduction, and maintained to at least $\sim 45 \mathrm{~km}$ depth. Our calculations indicate that the average fluidsaturated porosity of Layer 2 along L3 is 7\%, while at depths of $25-45 \mathrm{~km}$ beneath the fore-arc Layer 2 porosity is estimated to be $2.7-4 \%{ }^{[36]}$. Thus about half of $\mathrm{H}_{2} \mathrm{O}^{\text {pore }}$ in the upper crust is lost prior to $25 \mathrm{~km}$ depth, with the remaining $\mathrm{H}_{2} \mathrm{O}^{\text {pore }}$ transported deeper in the slab.

Our determination of the hydrated structure of the JdF plate has implications for the origin of ETS events and low-frequency earthquakes. These events are a characteristic of Cascadia and other warm subduction zones ${ }^{37,38}$, occurring around the mantle wedge corner, spatially distinct and down-dip from the seismogenic zone ${ }^{14}$. ETS are promoted by high pore-fluid pressures maintained by a combination of fluids released from the slab and decreased permeability above the slab due to serpentinization of the mantle wedge and silica deposition in the overlying continental crust just up-dip of the mantle wedge tip ${ }^{14,39-41}$. At Cascadia the fluid source must be at and/or down-dip from the $\sim 40 \mathrm{~km}$ depth 
level of the slab interface, as the majority of tremors occur directly above this interface $\operatorname{depth}^{42}$ (Fig. 1). Our finding of an essentially dry incoming lower crust and mantle implies that fluids released from the subducting upper crust are the most likely source for fluid-mediated tremor.

\section{Implications for deep slab processes and arc magmatism}

The oceanic mantle is potentially the largest water reservoir entering subduction zones and the only one with the capacity to carry substantial amounts of water to sub-arc depths ${ }^{1}$ and influence deep slab processes such as intra-slab seismicity as well as genesis of arc magmas. Intra-slab seismicity beneath central Cascadia is very sparse, aside from seismicity clusters beneath the Strait of Georgia-Puget Sound region and northern California (Fig. 1), which are thought to result from flexural stresses associated with warping of the plate and N-S compression between the Pacific and JdF plates ${ }^{20,24,43}$. Low levels of intra-slab seismicity are also observed within other sections of the global subduction system where the incoming plate enters the subduction zone at a young age, such as southern Chile trench and Nankai Trough.

Hydrous melting of the mantle wedge triggered by slab-derived fluids is considered the main mechanism that leads to arc magmatism. With the exception of Mt. Shasta in the southern Cascades ${ }^{44}$, water contents in arc magmas in the Cascades ${ }^{17,45}$ are lower than at any other subduction zone, with some arc magmas in central Oregon being among the driest globally ${ }^{46}$. This, and the general depletion in fluid-mobile elements characteristic

of slab contribution to arc magmatism ${ }^{47}$, have been interpreted as suggesting that at Cascadia, decompression melting of a convecting mantle wedge dominates over slabderived hydrous melting as the source of $\operatorname{arc}$ magmas ${ }^{48}$.

Our finding that the oceanic mantle entering central Cascadia is very poorly hydrated supports this hypothesis and explains the low levels of intra-slab seismicity at Cascadia, 
both of which may be general features of warm subduction zones. In these settings, only anomalously hydrated features in the incoming plate may locally contribute to these processes. For example, south of our survey area the incoming Gorda plate may be more hydrated due to its extensive deformation ${ }^{49}$ (Fig. 1) than what we find for the JdF plate, which would explain why southernmost Cascades magma compositions are consistent with a much wetter slab mantle $(2 \mathrm{wt} \% \text { water })^{17}$. Differences such as this between our results and previous assumptions on the content, mode of storage, and distribution of water within the JdF plate ${ }^{1,7,15,17,41}$ further highlight the need for a systematic quantification of incoming-plate $\mathrm{H}_{2} \mathrm{O}^{\text {pore }}$ and $\mathrm{H}_{2} \mathrm{O}^{+}$at crustal and mantle levels at other subduction zones where previous estimates of plate hydration from seismic velocities are incomplete (Table S1) and may be overestimated ${ }^{8,50}$.

\section{References}

1 van Keken, P. E., Hacker, B. R., Syracuse, E. M. \& Abers, G. A. Subduction factory: 4. Depth-dependent flux of $\mathrm{H}_{2} \mathrm{O}$ from subducting slabs worldwide. $J$. Geophys. Res. 116, B01401 (2011).

2 Hacker, B. R. H2O subduction beyond arcs. Geochem. Geophys. Geosyst. 9, Q03001 (2008).

3 Alt, J. C., Honnorez, J., Laverne, C. \& Emmerman, R. Hydrothermal alteration of a $1 \mathrm{~km}$ section through the upper oceanic crust, Deep Sea Drilling Project Hole 504B: mineralogy, chemistry, and evolution of sea-water-basalt interactions. $J$. Geophys. Res. 91, 10309-10335 (1986).

$4 \quad$ Billen, M. I. \& Gurnis, M. A low viscosity wedge in subduction zones. Earth Planet. Sci. Lett. 193, 227-236 (2001).

5 Tatsumi, Y. Migration of fluid phases and genesis of basalt magmas in subduction zones. J. Geophys. Res. 94, 4697-4707 (1989).

6 Magee, M. E. \& Zoback, M. D. Evidence for a weak intraplate thrust fault along the northern Japan subduction zone and implications for the mechanics of thrust faulting and fluid expulsion. Geology 21, 809-812 (1993).

7 Jarrard, R. D. Subduction fluxes of water, carbon dioxide, chlorine, and potassium. Geochem. Geophys. Geosyst. 4, 8905 (2003).

$8 \quad$ Korenaga, J. On the extent of mantle hydration caused by plate bending. Earth Planet. Sci. Lett. 457, 1-9 (2017).

9 Wilson, D. S. in The Cascadia Subduction Zone and Related Subduction Systems. Seismic Structure, Intraslab Earthquakes and Processes, and Earthquake 
Hazards (eds S. Kirby, K. Wang, \& S. Dunlop) 9-12 (U.S. Geol. Survey OpenFile Report 02-328, 2002).

Wada, I. \& Wang, K. Common depth of slab-mantle decoupling: Reconciling diversity and uniformity of subduction zones. Geochem. Geophys. Geosyst. 10, Q10009 (2009).

Malvoisin, B., Brunet, F., Carlut, J., Rouméjon, S. \& Cannat, M. Serpentinization of oceanic peridotites: 2. Kinetics and processes of San Carlos olivine hydrothermal alteration. J. Geophys. Res. 117, B04102 (2012).

Bostock, M. G., Hyndman, R. D., Rondenay, S. \& Peacock, S. M. An inverted continental Moho and serpentinization of the forearc mantle. Nature 417, 536-538 (2002).

Audet, P., Bostock, M. G., Christensen, N. I. \& Peacock, S. M. Seismic evidence for overpressured subducted oceanic crust and megathrust fault sealing. Nature 457, 76-78 (2009).

Gao, X. \& Wang, K. Rheological separation of the megathrust seismogenic zone and episodic tremor and slip. Nature 543, 416-419 (2017).

Preston, L. A., Creager, K. C., Crosson, R. S., Brocher, T. M. \& Trehu, A. M. Intraslab Earthquakes: dehydration of the Cascadia slab. Science 302, 1197-1200 (2003).

McGary, R. S., Evans, R. L., Wannamaker, P. E., Elsenbeck, J. \& Rondenay, S. Pathway from subducting slab to surface for melt and fluids beneath Mount Rainier. Nature 511, 338-340 (2014).

Walowski, K. J., Wallace, P. J., Hauri, E. H., Wada, I. \& Clynne, M. A. Slab melting beneath the Cascade Arc driven by dehydration of altered oceanic peridotite. Nat. Geosci., 404-408 (2015).

Horning, G. et al. A 2-D Tomographic Model of the Juan de Fuca Plate from Accretion at Axial Seamount to Subduction at the Cascadia Margin from an Active Source OBS survey. J. Geophys. Res. 121, 5859-5879 (2016).

Nedimović, M. R. et al. Upper crustal evolution across the Juan de Fuca Ridge flanks. Geochem. Geophys. Geosyst. 9, Q09006 (2008).

Nedimović, M. R., Bohnenstiehl, D. R., Carbotte, S. M., Canales, J. P. \& Dziak, R. P. Faulting and hydration of the Juan de Fuca Plate system. Earth Planet. Sci. Lett. 284, 94-102 (2009).

Newman, K. R., Nedimović, M. R., Canales, J. P. \& Carbotte, S. M. Evolution of seismic layer 2B across the Juan de Fuca Ridge from hydrophone streamer 2D traveltime tomography. Geochem. Geophys. Geosyst. 12, Q05009 (2011). Wang, K., He, J. \& Davis, E. E. Transform push, oblique subduction resistance, and intraplate stress of the Juan de Fuca plate. J. Geophys. Res. 102, 661-674 (1997).

Govers, R. \& Meijer, P. T. On the dynamics of the Juan de Fuca plate. Earth Planet. Sci. Lett. 189, 115-131 (2001).

Han, S. et al. Seismic reflection imaging of the Juan de Fuca plate from ridge to trench; new constraints on the distribution of faulting and evolution of the crust prior to subduction. J. Geophys. Res. 121, 1849-1872 (2016).

Kuster, G. T. \& Toksöz, M. N. Velocity and attenuation of seismic waves in twophase media: Part I. Theoretical formulations. Geophysics 39, 587-606 (1974). 
MacKay, M. E. Structural variation and landward vergence at the toe of the Oregon prism. Tectonics 14, 1309-1320 (1995).

Adam, J., Klaeschen, D., Kukowski, N. \& Flueh, E. R. Upward delamination of Cascadia Basin sediment infill with landward frontal accretion thrusting caused by rapid glacial age material flux. Tectonics 23, TC3009 (2004).

Booth-Rea, G., Klaeschen, D., Grevemeyer, I. \& Reston, T. Heterogeneous deformation in the Cascadia convergent margin and its relation to thermal gradient (Washington, NW USA). Tectonics 27, TC4005 (2008).

Grevemeyer, I. et al. Heat flow and bending-related faulting at subduction trenches: Case studies offshore of Nicaragua and Central Chile. Earth Planet. Sci. Lett. 236, 238-248 (2005).

Ranero, C. R., Phipps Morgan, J., McIntosh, K. \& Reichert, C. Bending-related faulting and mantle serpentinization at the Middle America trench. Nature 425, 367-373 (2003).

Goldfinger, C. et al. The importance of site selection, sediment supply, and hydrodynamics: A case study of submarine paleoseismology on the northern Cascadia margin, Washington USA. Mar. Geol. 384, 4-46 (2017).

Poli, P., Maksymowicz, A. \& Ruiz, S. The Mw8.3 Illapel earthquake (Chile): Preseismic and postseismic activity associated with hydrated slab structures. Geology 45, 247-250 (2017).

Wang, K. \& Tréhu, A. M. Invited review paper: Some outstanding issues in the study of great megathrust earthquakes - The Cascadia example. J. Geodyn. 98, 118 (2016).

Audet, P., Bostock, M. G., Boyarko, D. C., Brudzinski, M. R. \& Allen, R. M. Slab morphology in the Cascadia gore arc and its relation to episodic tremor and slip. J. Geophys. Res. 115, B00A16 (2010).

Hansen, R. T. J., Bostock, M. G. \& Christensen, N. I. Nature of the low velocity zone in Cascadia from receiver function waveform inversion. Earth Planet. Sci. Lett. 337-338, 25-38 (2012).

Peacock, S. M., Christensen, N. I., Bostock, M. G. \& Audet, P. High pore pressures and porosity at $35 \mathrm{~km}$ depth in the Cascadia subduction zone. Geology 39, 471-474 (2011).

Dragert, H., Wang, K. \& James, T. S. A silent slip event on the deeper Cascadia subduction interface. Science 292, 1525-1528 (2001).

Shelly, D. R., Beroza, G. C. \& Ide, S. Non-volcanic tremor and low-frequency earthquake swarms. Nature 446, 305-307 (2007).

Audet, P. \& Kim, Y.-H. Teleseismic constraints on the geological environment of deep episodic slow earthquakes in subduction zone forearcs: A review.

Tectonophys. 670, 1-15 (2016).

Audet, P. \& Bürgmann, R. Possible control of subduction zone slow-earthquake periodicity by silica enrichment. Nature 510, 389-392 (2014).

Hyndman, R. D., McCrory, P. A., Wech, A., Kao, H. \& Ague, J. Cascadia subducting plate fluids channelled to fore-arc mantle corner: ETS and silica deposition. J. Geophys. Res. 120, 4344-4358 (2015). 
Boyarko, D. C., Brudzinski, M. R., Porritt, R. W., Allen, R. M. \& Trehu, A. M. Automated detection and location of tectonic tremor along the entire Cascadia margin from 2005 to 2011. Earth Planet. Sci. Lett. 430, 160-170 (2015).

McCrory, P. A., Blair, J. L., Waldhauser, F. \& Oppenheimer, D. H. Juan de Fuca slab geometry and its relation to Wadati-Benioff zone seismicity. J. Geophys. Res. 117, B09306 (2012).

Sisson, T. W. \& Layne, G. D. H2O in basalt and basaltic andesite glass inclusions from four subduction-related volcanoes. Earth Planet. Sci. Lett. 117, 619-635 (1993).

45 Ruscitto, D. M., Wallace, P. J., Johnson, E. R., Kent, A. J. R. \& Bindeman, I. N. Volatile contents of mafic magmas from cinder cones in the Central Oregon High Cascades: Implications for magma formation and mantle conditions in a hot arc. Earth Planet. Sci. Lett. 298, 153-161 (2010). Plank, T., Kelley, K. A., Zimmer, M. M., Hauri, E. H. \& Wallace, P. J. Why do mafic arc magmas contain $\sim 4 \mathrm{wt} \%$ water on average? Earth Planet. Sci. Lett. 364, 168-179 (2013).

47 Leeman, W. P., Tonarini, S., Chan, L. H. \& Borg, L. E. Boron and lithium isotopic variations in a hot subduction zone- the southern Washington Cascades. Chem. Geol. 212, 101-124 (2004). Leeman, W. P., Lewis, J. F., Evarts, R. C., Conrey, R. M. \& Streck, M. J. Petrologic constraints on the thermal structure of the Cascades arc. J. Volcanol. Geotherm. Res. 140, 67-105 (2005).

49 Wilson, D. S. A kinematic model for the Gorda deformation zone as a diffuse southern boundary of the Juan de Fuca plate. J. Geophys. Res. 91, 10259-10269 (1986).

50 Miller, N. C. \& Lizarralde, D. Finite-frequency wave propagation through outer rise faults and seismic measurements of upper mantle hydration. Geophys. Res. Lett. 43, 7982-7990 (2016).

\section{Acknowledgements}

This research was funded by the US NSF. We thank the RV M.G. Langseth's and RV Oceanus' Captains, crews, and technical staffs, and the US Ocean Bottom Seismograph Instrument Pool (OBSIP) managers and technical staff for their efforts, which made possible the success of cruises MGL1211 and OC1206A. We thank K. Wang for his review, which improved the manuscript.

\section{Author Contributions}


All authors are co-PIs of the project and contributed to interpretation of results and manuscript writing. J.P.C. conducted the OBS wide-angle seismic data analysis, tomography modelling, and water content calculations, and led the manuscript writing with substantial contributions from all co-authors. S.M.C. was the program inception and planning leader, and the Chief Scientist for RV Langseth Cruise MGL0812. J.P.C. and H.C. were co-Chief Scientists for RV Oceanus Cruise OC1206A.

\section{Competing financial interests}

The authors declare no competing financial interests.

\section{Figure 1 | Subduction flux of water and seismicity of Cascadia and adjacent oceanic}

plates. Subduction fluxes of upper crustal and lower crustal + mantle $\mathrm{H}_{2} \mathrm{O}$ along profile $\mathrm{L} 3$ are shown as light/dark blue bands oriented in the direction of JdF convergence relative to North America ${ }^{9}$ (black arrow).Yellow dots represent epicentres of upper, continental plate events, while red dots are epicentres in the incoming and downgoing Explorer, JdF and Gorda plates (Jan 1975-Jan 2015, ANSS catalogue). Green shading highlights the increased seismicity of the southeastern sector of the JdF plate. Thick solid lines are seismic profiles. Black/white dashed lines are Cascadia deformation front (CDF) and other plate boundaries. Dashed lines delineate propagator wakes and shear zones in the JdF plate determined from disruptions of marine magnetic anomalies (long-dash) and from plate motion reconstructions constrained by marine magnetic anomalies (short-

dash) ${ }^{9}$. Brown contours (labelled in $\mathrm{km}$ ) correspond to depth to top of the slab ${ }^{43}$. White triangles are main arc stratovolcanoes. Vertical purple bars mark megathrust 
paleoseismicity segmentation ${ }^{31}$. Green line with bars represent the centroid and tremor segmentation $^{42}$.

Figure 2 | Vp structure of the JdF plate seaward from the CDF. a, Tomography model along profile L3 with contours every $0.5 \mathrm{~km} \mathrm{~s}^{-1}$. Numbers along seafloor are OBSs. Dashed lines are isotherms. White line and white squares locate the protodécollement $^{26-28} . V p$ averages at selected depth intervals corrected for crustal anisotropy are shown as coloured bands (width is $\pm 1 \sigma$ ) in $\mathbf{b}$ (sub-décollement sediments and upper crust) and ( (lower crust and upper mantle). Solid and dashed colour lines are $V p$ estimates based on dominant lithology and thermal structure at each depth interval. In c, Dry mantle $V p$ is shown for no mantle anisotropy and for $6 \%$ azimuthal anisotropy with fast propagation along the spreading direction (dashed and solid green lines, respectively). Grey shadings locate propagator wakes.

Figure 3 | Water content of the JdF plate seaward from the CDF. a, $\mathrm{H}_{2} \mathrm{O}^{\text {pore }}$ and $\mathrm{H}_{2} \mathrm{O}^{+}$in sub-décollement sediments and upper crust; $\mathbf{b}, \mathrm{H}_{2} \mathrm{O}^{\text {pore }}$ in the lower crust and upper mantle; c, $\mathrm{H}_{2} \mathrm{O}^{+}$in the lower crust and upper mantle (for a talc-bearing alteration assemblage); d, $\mathrm{H}_{2} \mathrm{O}^{+}$in the upper mantle for a serpentine-bearing alteration assemblage. Lines show the mean of the 100 Monte Carlo solutions obtained from randomized input parameters (Methods), and coloured bands are upper and lower bounds of the $99 \%$ confidence intervals of the estimates of the mean. Grey shadings as in Fig. 2. 


\section{Methods}

Data Acquisition and Processing. Multichannel seismic (MCS) reflection and ocean bottom seismometer (OBS) wide-angle seismic data ${ }^{51,52}$ acquisition is described in detail in refs. ${ }^{18,24}$. Twenty-six OBSs spaced $15 \mathrm{~km}$ apart were deployed along profile L3 (Fig. 1, 2a). These instruments first recorded data from airgun shots fired every $500 \mathrm{~m}$ for wide-angle refraction, and a second time from closely spaced shots $(37.5 \mathrm{~m})$ for MCS streamer imaging. OBS records were filtered between 5 and $20 \mathrm{~Hz}$. Predictive deconvolution was applied to wide-angle records to improve identification of the wideangle Moho $(P m P)$ triplication. MCS data were processed up to a post-stack migrated section with the objective of imaging the igneous basement, which was used as a constraint in the tomographic inversions. MCS processing consisted of: geometry definition, velocity analysis, spherical divergence and surface-consistent amplitude corrections, 3-60 Hz band-pass filtering, normal move-out correction, stacking, seafloor multiple muting, and post-stack F-K migration.

Traveltimes of first-arriving sedimentary phases $(P S)$ were handpicked in the OBS records of the MCS shots (Supplementary Appendix A). Traveltimes for sub-basement crustal refractions $(P g), P m P$, and sub-Moho mantle refractions $(P n)$ were handpicked in the wide-angle OBS records (Supplementary Appendix B). Pick statistics are given in Supplementary Table S2.

Tomography Modelling. To solve for the 2D Vp structure and depth to the Moho we applied a joint refraction-reflection travel-time tomography method ${ }^{53}$, a non-linear inversion regularised by imposing damping and smoothing constraints. We followed a top-down modeling approach as described in ref. ${ }^{18}$ : (1) First we inverted for $V p$ within 
the sediments using the traveltimes of sedimentary refractions $P s$ picked on the OBS record sections for the closely spaced $(37.5 \mathrm{~m}) \mathrm{MCS}$ shots. Seafloor depth along the profile was kept fixed and was obtained from the $R V$ Langseth EM-122 multi-beam echosounder. (2) We then proceeded to invert for crustal $V p$ and Moho depth using the crustal refractions $P g$ and Moho reflections $P m P$ traveltimes picked on the OBS record sections for the widely spaced shots $(500 \mathrm{~m})$. For this step the structure obtained in the previous stage above a pre-determined interface (basement, obtained from the two-way travel time measured in the MCS image converted to depth using the sediment velocities obtained in the previous stage) was kept fixed. (3) Lastly we inverted for mantle velocities using the $P n$ traveltimes, keeping fixed the structure obtained in the previous stage above the Moho interface.

To minimise possible biases in the inversion result due to the choice of starting model and to obtain a quantitative measure of the model uncertainty, we followed a Monte Carlo approach and conducted a large number (100) of tomographic inversions at each stage starting with different, randomised 1D models ${ }^{53}$ (Fig. S1). For each stage, the preferred velocity model was then taken as the mean of the 100 Monte Carlo solutions (Fig. S2). Data fit statistics are given in the Supplementary Information Table 1. Uncertainties reported in the text for sediment thickness and $V p$ values represent $1 \sigma$ of the Monte Carlo solutions (Supplementary Fig. S3).

To simplify the estimation of water content from the tomography model we focus our analysis to certain depth intervals representative of the main seismic units of oceanic crust: extrusive volcanics (Layer 2A), with a thickness of $370 \mathrm{~m}^{[19]}$, dikes (Layer 2B, 0.5$1.5 \mathrm{~km}$ below basement), gabbros (Layer 3, 0.5-2.5 km above Moho), and upper mantle (0.5-1.5 km below Moho). We also applied an anisotropic correction to the tomography model to determine what would be the $V p$ measured in the spreading direction, thus orthogonal to the main orientation of faults and cracks, which is the most sensitive to the 
presence of vertically aligned cracks ${ }^{54}$. To do this we compare the $V p$ structures obtained along L1 ${ }^{[18]}$ and along L3 (this study) at the intersection between both profiles (Supplementary Fig. S7). We find that the differences in $V p$ measured along L1 and L3 can be explained by crustal anisotropy that decreases linearly with depth, from $25 \%$ at the basement to $0 \%$ at $1.6 \mathrm{~km}$ below basement. This upper crustal anisotropy is of much larger magnitude that what is commonly reported ${ }^{54}$, but is comparable to the high anisotropy values that characterised young crust at the JdF ridge: $39 \%$ in the upper $\sim 500$ $\mathrm{m}$ at the Cleft segment ${ }^{55}$, and locally exceeding $15 \%$ in the upper $\sim 1 \mathrm{~km}$ at the Endeavour segment ${ }^{56}$.

To interpret the mantle velocities we explore the effect of azimuthal mantle anisotropy in our measurements. Data recorded along fan profiles F1 and F2 (Fig. 1) indicate that mantle anisotropy in young JdF plate and near the CDF offshore Washington is $5.8 \pm 1.2 \%$ and $8.4 \pm 1.5 \%$, respectively, with fast propagation along the spreading direction (Fig. S4 and S5). These values are comparable to the magnitudes of mantle anisotropy measured in both young $\left(6 \%^{[57]}\right)$ and old $\left(8.5-9.8 \%{ }^{[58]}\right)$ fast-spreading plates. For simplicity, we assume a mantle anisotropy of $6 \%$ with fast propagation aligned along the spreading direction.

Thermal Structure and Reference $\boldsymbol{V} \boldsymbol{p}$. We approximate the thermal structure of the plate along our profile by extracting the $1 \mathrm{D}$ geotherm from the $2 \mathrm{D}$ thermal model of ${ }^{18}$ at the intersection of profiles L1 and L3, and extrapolating it along L3. We calculated reference $V p$ for major lithologies representative of the upper crust (basalt or diabase), gabbro (lower crust), and peridotite (upper mantle) at the temperatures predicted by the thermal model within the chosen depth intervals along our profile (Fig. 2). $P$-wave velocity values for unaltered lithologies at room temperature and the temperature dependence of $V p$ used in these calculations are given in Supplementary Table S3. 
Water Content Estimates. For the sub-proto-décollement sediments, we convert the averaged tomography derived $V p$ to porosity using Eq. 9 of ref. ${ }^{59}$ for highly consolidated sediments assuming a dominant shale composition, consistent with the composition in the 400-m-above-basement of hemipelagic sediments and turbidites drilled at ODP Leg 168 Hole 1027 in $3.6 \mathrm{Ma} \mathrm{JdF}$ plate $(\sim 75 \% \text { clays, } \sim 25 \% \text { silts, } \sim 0 \% \text { sands })^{60}$. We then estimate the amount of $\mathrm{H}_{2} \mathrm{O}^{\text {pore }}$ assuming an average sediment density of $2,500 \mathrm{~kg} \mathrm{~m}^{-3}[61]$.

For the crustal and mantle layers, we assume a certain maximum porosity $\phi_{\max }$ that can be filled with any combination of fluid water and hydrated alteration mineralogies. The fraction of material that is occupied by $\mathrm{H}_{2} \mathrm{O}^{\text {pore }}$ is parameterised as $\phi_{\max } \cdot \phi_{\text {pore }}$, and the fraction of material that is occupied by hydrated minerals is parameterised as $\phi_{\max } \cdot \phi_{s t r u c t}$, such that $\phi_{\text {pore }}+\phi_{\text {struct }}=1$. By fixing the value of $\phi_{\max }$ and the crack aspect ratio, we can then use effective medium theory ${ }^{25}$ to calculate the unique combination of $\left[\phi_{\text {pore }}, \phi_{\text {struct }}\right]$ required to explain the differences in $V p$ between our tomography model (after correction for crustal anisotropy when appropriate) and the temperature-corrected reference $V p$, for the host lithologies and depth intervals described above (Fig. 2b, c). $\phi_{\text {pore }}$ can be then converted directly to $\mathrm{H}_{2} \mathrm{O}^{\text {pore }}$. $\mathrm{H}_{2} \mathrm{O}^{+}$can be estimated from $\phi_{\text {struct }}$ by choosing a hydrated alteration mineral assemblage for each layer.

Parameters and uncertainties. To account for uncertainties in the parameters that have the largest influences in our water content estimates (temperature, $V p, \phi_{\max }$, crack aspect ratio), and the trade-offs between them, we adopted a Monte Carlo statistical strategy consisting of generating a large $(\mathrm{N}=100)$ number of solutions obtained from randomly generated parameter values. This approach allows us to obtain solutions that represent the full parameter spaces in a statistical manner. Preferred water contents along profile L3 are then estimated from the mean of all possible solutions, with water content uncertainties represented by the $99 \%$ confidence intervals of the estimates of the means. 
For $V p$ at each layer we use each of the Monte Carlo tomography models described above. For temperature, we add to the average layer temperature described above a random perturbation obtained from a uniform probability distribution between $\pm 100{ }^{\circ} \mathrm{C}$ (Fig. S8).

Layer 2A. For $\phi_{\max }$ we use random values obtained from a normal distribution (Supplementary Fig. S9d) derived from published measurements (Supplementary Fig. S9c). Crack aspect ratios (Supplementary Fig. S9e) were obtained from effective medium theory ${ }^{25}$ by combining the randomized $\phi_{\max }$ values with random Layer $2 \mathrm{~A} V p$ values (Supplementary Fig. S9b) derived from published measurements (Supplementary Fig. S9a).

Layer 2B. Because of insufficient estimates of $\phi_{\max }$ in the dike section in zero-age crust we use an empirical relationship between $V p$ and $\phi_{\max }$ (Supplementary Fig. S10) to convert random Layer 2B Vp values (Supplementary Fig. S10b) derived from published measurements (Supplementary Fig. S10a) into a random distribution of porosities for Layer 2B (Supplementary Fig. S10c). As for Layer 2A, crack aspect ratios in layer 2B (Supplementary Fig. S10d) were obtained from effective medium theory ${ }^{25}$ by combining the randomized $\phi_{\max }$ values with the random $V p$ values.

Layer 3. For $\phi_{\max }$ we use random values obtained from a log-normal distribution (Supplementary Fig. S11d) derived from published measurements in gabbroic samples from drill cores (Supplementary Fig. S11c). Crack aspect ratios (Supplementary Fig. S11e) were obtained from effective medium theory ${ }^{25}$ by combining the randomized $\phi_{\max }$ values with random $V p$ values (Supplementary Fig. S11b) derived from the same gabbroic samples (Supplementary Fig. S11a).

Mantle. For the mantle we assume that the random distributions of $\phi_{\max }$ and crack aspect ratios are not different from those for the lower crust (Supplementary Fig. S11). 
This assumption is valid because we are only estimating hydration of the uppermost mantle down to $1.5 \mathrm{~km}$ below the Moho where conditions are not much different from those within $2 \mathrm{~km}$ above the Moho, and it is supported by porosity estimates of the lower crust and upper mantle from electromagnetic data off the Middle America Trench away from the influence of subduction bending faulting ${ }^{62}$.

Alteration mineralogies. For $\mathrm{H}_{2} \mathrm{O}^{+}$in the upper crust we assume an alteration assemblage consisting of $80 \mathrm{wt} \%$ saponite and $20 \mathrm{wt} \%$ celadonite for Layer $2 \mathrm{~A}^{3,7}$, and of $16.55 \mathrm{wt} \%$ chlorite, $75.25 \mathrm{wt} \%$ actinolite, and $8.2 \mathrm{wt} \%$ albite for Layer $2 \mathrm{~B}^{3}$. These mineralogies were kept constant in all of the Monte Carlo calculations because they are based on in situ sampling and represent well the alteration of upper oceanic crust.

For $\mathrm{H}_{2} \mathrm{O}^{+}$in the lower crust we use a temperature-dependent alteration assemblage, as predicted for hydrothermal alteration of olivine gabbro (Supplementary Fig. S12) ${ }^{63}$. Since the water content of these assemblages are very sensitive to temperature (Supplementary Fig. S12) in the range of temperatures we estimate for the lower crust $\left(350^{\circ} \mathrm{C}\right.$, Fig. $\left.2 \mathrm{a}\right)$, the Monte Carlo solutions for $\mathrm{H}_{2} \mathrm{O}^{+}$in the lower crust use different mineral alteration water contents based on the random temperature perturbations (Supplementary Fig. S8).

For the upper mantle we calculate $\mathrm{H}_{2} \mathrm{O}^{+}$using two possible alteration assemblages: $41 \mathrm{wt} \%$ talc $+23 \mathrm{wt} \%$ chlorite $+36 \mathrm{wt} \%$ amphibole, and $67.8 \mathrm{wt} \%$ serpentine +19.8 $\mathrm{wt} \%$ chlorite $+12.4 \mathrm{wt} \%$ amphibole ${ }^{64} . \mathrm{N}=100$ Monte Carlo solutions were calculated with each assemblage.

The elastic parameters and water content for the host rocks and alteration assemblages, at the pressure and temperature conditions appropriate for each depth interval considered along our profile, were calculated using the workbook of ${ }^{65}$ (Supplementary Table S4). 
Subduction water flux at Cascadia. We determine the subduction flux of crustal and mantle water by integrating our water content estimates over a column consisting of 3 layers (2-km thick upper crust, 4-km-thick lower crust, and 2-km-thick upper mantle). For these calculations we use the mantle water content estimates assuming no anisotropy south of the $45^{\circ} 05^{\prime} \mathrm{N}$ propagator and $6 \%$ to the north of it for a talc + chlorite + amphibole alteration mineral assemblage. We chose the talc-bearing over the serpentine-bearing assemblage because the modelled mantle temperatures are at the upper limit of the stability field for antigorite at $3 \mathrm{kbar}^{[66]}$ while talc is stable at these conditions ${ }^{67}$. Our water flux calculations do not include the contribution from subducted sediments because of the high uncertainties in the thickness of sediments that are being subducted resulting from the décollement changing stratigraphic level both along and across the margin ${ }^{26}$. This approximation is reasonable for much of the margin in our study area, as the available data indicate little sediment is being subducted offshore Washington ${ }^{27,28}$. Offshore central Oregon, where subducting sediment thickness is greater ${ }^{26}$ (Fig. 2a), the sub-proto-décollement $\mathrm{H}_{2} \mathrm{O}^{\text {pore }}$ content estimated south of $45^{\circ} 25^{\prime} \mathrm{N}$ (Fig. 3a) would add $2,100 \pm 300 \mathrm{Tg} \mathrm{Myr}^{-1} \mathrm{~km}^{-1}$ to the subduction flux of water.

Data availability. OBS Data used in this research were provided by instruments from the OBSIP (http://www.obsip.org) which is funded by the US NSF. OBSIP data are archived at the IRIS Data Management Center (http://www.iris.edu), network code X6-2012 (doi:10.7914/SN/X6_2012). MCS data are available from the Marine Geoscience Data System (doi:10.1594/IEDA/319000).

Code availability. Code for traveltime tomography tomo $2 d$ is available from http://people.earth.yale.edu/software/jun-korenaga.

\section{References only in Methods}


Canales, J. P. \& Carbotte, S. (International Federation of Digital Seismograph Networks. Other/Seismic Network. doi:10.7914/SN/X6_2012, 2012).

Carbotte, S. M., Canales, J. P., Carton, H. \& Nedimović, M. R. Multi-channel seismic shot data from the Cascadia subduction zone acquired during the $\mathrm{R} / \mathrm{V}$ Marcus Langseth expedition MGL1211 (2012). Integrated Earth Data Applications (IEDA). doi:10.1594/IEDA/319000. (2014).

Korenaga, J. et al. Crustal structure of the southeast Greenland margin from joint refraction and reflection seismic tomography. J. Geophys. Res. 105, 21,59121,614 (2000).

Dunn, R. A. \& Toomey, D. R. Crack-induced seismic anisotropy in the oceanic crust across the East Pacific Rise $\left(9^{\circ} 30^{\prime} \mathrm{N}\right)$. Earth Planet. Sci. Lett. 189, 9-17 (2001).

McDonald, M. A., Webb, S. C., Hildebrand, J. A., Cornuelle, B. D. \& Fox, C. G. Seismic structure and anisotropy of the Juan de Fuca Ridge at $45^{\circ}$ N. J. Geophys. Res. 99, 4857-4873 (1994).

Weekly, R. T., Wilcock, W. S. D., Toomey, D. G., Hooft, E. E. E. \& Kim, E. Upper crustal seismic structure of the Endeavour segment, Juan de Fuca Ridge from traveltime tomography: Implications for oceanic crustal accretion. Geochem. Geophys. Geosyst. 15, 1296-1315 (2014).

Toomey, D. R., Jousselin, D., Dunn, R. A., Wilcock, W. S. D. \& Detrick, R. S. Skew of mantle upwelling beneath the East Pacific Rise governs segmentation. Nature 446, 409-414 (2007).

Kodaira, S. et al. Seismological evidence of mantle flow driving plate motions at a palaeo-spreading centre. Nat. Geosci. 7, 371-375 (2014).

Erickson, S. N. \& Jarrard, R. D. Velocity-porosity relationships for watersaturated siliciclastic sediments. J. Geophys. Res. 103, 30,385-30,406 (1998). Cavin, A., Underwood, M., Fisher, A. \& Johnston-Karas, A. in Proc. ODP, Sci. Results Vol. 168 (eds A. Fisher, E.E. Davis, \& C. Escutia) 67-84 (Ocean Drilling Program, 2000).

Hamilton, E. L. Sound velocity-density relations in sea-floor sediments and rocks. J. Acoust. Soc. Am. 63, 366-377 (1978).

Naif, S., Key, K., Constable, S. \& Evans, R. L. Water-rich bending faults at the Middle America trench. Geochem. Geophys. Geosyst. 16, 2582-2597 (2015). McCollom, T. M. \& Shock, E. L. Fluid-rock interactions in the lower oceanic crust: Thermodynamic models of hydrothermal alteration. J. Geophys. Res. 103, 547-575 (1998).

Schmidt, M. W. \& Poli, S. Experimentally based water budgets for dehydrating slabs and consequences for arc magma generation. Earth Planet. Sci. Lett. 163, 361-379 (1998).

Hacker, B. R. \& Abers, G. A. Subduction Factory 3: an Excel worksheet and macro for calculating the densities, seismic wave speeds, and $\mathrm{H} 2 \mathrm{O}$ contents of minerals and rocks at pressure and temperature. Geochem. Geophys. Geosyst. 5, Q01005 (2004).

Evans, B. W. The serpentine multisystem revisited: Chrysotile is metastable. Int. Geol. Rev. 46, 479-506 (2004). 
67 Johannes, W. Experimental investigation of the reaction

Forsterite $+\mathrm{H} 2 \mathrm{O}=$ Serpentinite + Brucite. Contrib. Mineral. Petrol. 19, 309-315

(1968). 
a Latitude along profile L3

$\begin{array}{lllllll}44^{\circ} 30^{\prime} \mathrm{N} & 45^{\circ} 00^{\prime} \mathrm{N} & 45^{\circ} 30^{\prime} \mathrm{N} & 46^{\circ} 00^{\prime} \mathrm{N} & 46^{\circ} 30^{\prime} \mathrm{N} & 47^{\circ} 00^{\prime} \mathrm{N} & 47^{\circ} 30^{\prime} \mathrm{N}\end{array}$ \begin{tabular}{lllllllllllllllllllllllllllll}
2 & 0 & 02 & 03 & 04 & 05 & 06 & 07 & 08 & 09 & 10 & 11 & 12 & 13 & 14 & 15 & 16 & 17 & 18 & 19 & 20 & 21 & 22 & 23 & 24 & 25 & 26 \\
\hline
\end{tabular} 4 proto-décollement

1

12

14 $100^{\circ} \mathrm{C}=-\cdots \mathbf{x}^{2}$

$-200^{\circ} \mathrm{C}$

$-300^{\circ} \mathrm{C}$

$-400^{\circ} \mathrm{C}$

$-600^{\circ} \mathrm{C}$

$-50 \quad 0$

$50 \quad 100$

M1

Uun

Moho-

ThMuli in

b

$44^{\circ} 30^{\prime} \mathrm{N}$

$45^{\circ} 00^{\prime} \mathrm{N}$

$45^{\circ} 30^{\prime} \mathrm{N}$

$46^{\circ} 00^{\prime} \mathrm{N} \quad 46^{\circ} 30^{\prime} \mathrm{N}$

$47^{\circ} 00^{\prime} \mathrm{N}$

$47^{\circ} 30^{\prime} \mathrm{N}$

is 6.2 Upper crust and sub-décollement sediments

$\underline{E}$

4.6

3.8

3.0

$-50$

nis

basalt/diabase tomography seds $2 A$

0

100

150

200

250

300

350

c $\quad 44^{\circ} 30^{\prime} \mathrm{N} \quad 45^{\circ} 00^{\prime} \mathrm{N} \quad 45^{\circ} 30^{\prime} \mathrm{N} \quad 46^{\circ} 00^{\prime} \mathrm{N} \quad 46^{\circ} 30^{\prime} \mathrm{N} \quad 47^{\circ} 00^{\prime} \mathrm{N} \quad 47^{\circ} 30^{\prime} \mathrm{N}$

8.

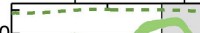

Upper mantle

7.6-tomography

- $\begin{aligned} & \text { dry mantle- }==-1 \\ & \text { anisotropy } 0 \%\end{aligned}$

\begin{tabular}{ll|l}
7.25 & & \\
\hline 6.8 & & \\
\hline-50 & 0 & 50
\end{tabular}

Lower crust tomography

gabbro

$\frac{\mathrm{km} \mathrm{s}^{-1}}{350}$

300 
Latitude along profile L3

a $\quad 44^{\circ} 30^{\prime} \mathrm{N} \quad 45^{\circ} 00^{\prime} \mathrm{N} \quad 45^{\circ} 30^{\prime} \mathrm{N} \quad 46^{\circ} 00^{\prime} \mathrm{N} \quad 46^{\circ} 30^{\prime} \mathrm{N} \quad 47^{\circ} 00^{\prime} \mathrm{N} \quad 47^{\circ} 30^{\prime} \mathrm{N}$

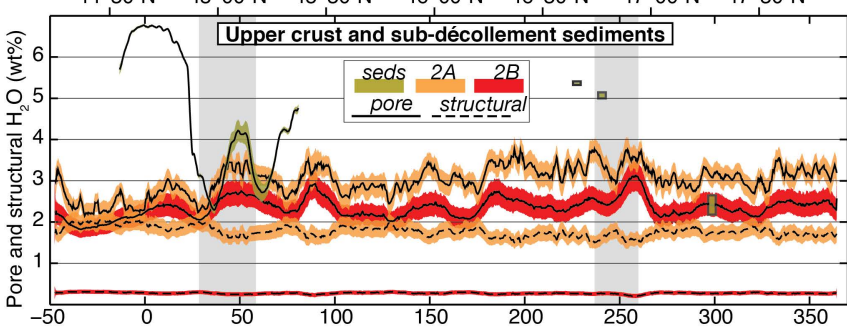

b $\quad 44^{\circ} 30^{\prime} \mathrm{N} \quad 45^{\circ} 00^{\prime} \mathrm{N} \quad 45^{\circ} 30^{\prime} \mathrm{N} \quad 46^{\circ} 00^{\prime} \mathrm{N} \quad 46^{\circ} 30^{\prime} \mathrm{N} \quad 47^{\circ} 00^{\prime} \mathrm{N} \quad 47^{\circ} 30^{\prime} \mathrm{N}$

0.25

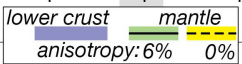

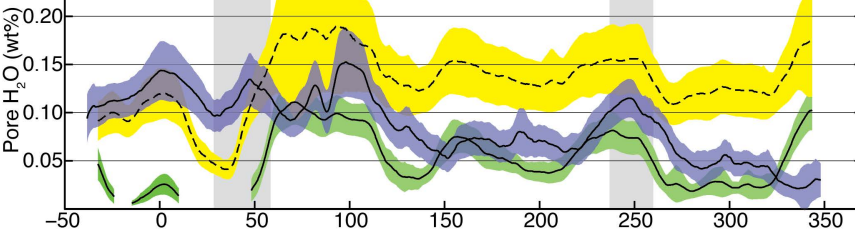

c $\quad 44^{\circ} 30^{\prime} \mathrm{N} \quad 45^{\circ} 00^{\prime} \mathrm{N} \quad 45^{\circ} 30^{\prime} \mathrm{N} \quad 46^{\circ} 00^{\prime} \mathrm{N} \quad 46^{\circ} 30^{\prime} \mathrm{N} \quad 47^{\circ} 00^{\prime} \mathrm{N} \quad 47^{\circ} 30^{\prime} \mathrm{N}$ Lower crust and upper mantle

๖

30.01

I

는

ڤั

\subsection{3 \\ Lower crust and upper mantle (talc+chlor+amph)}
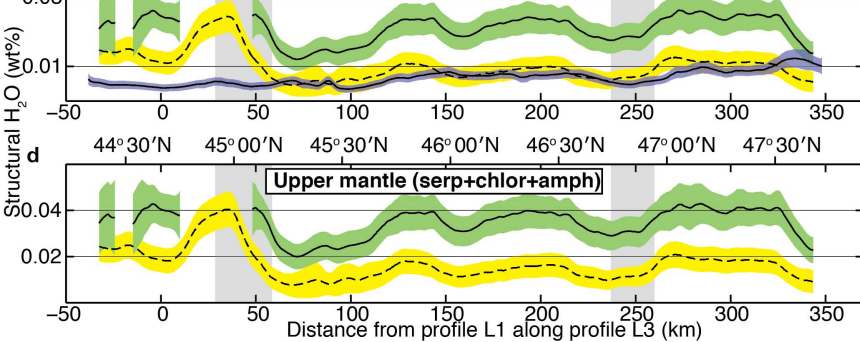